\title{
The Influence of Online Customer Reviews on Online Booking Intention in the Online B2C Travel Agent Industry in Indonesia
}

\author{
A. Pujianti ${ }^{1 *}$ Lili Adi Wibowo ${ }^{2,}$ Lisnawati $^{3}$ \\ ${ }^{1}$ Universitas Pendidikan Indonesia \\ ${ }^{2}$ Universitas Pendidikan Indonesia \\ ${ }^{3}$ Universitas Pendidikan Indonesia \\ *Corresponding author. Email: Anisapujianti@student.upi.edu
}

\begin{abstract}
The purpose of this research is to find out the influence of online customer review on online booking intention in milenial use online travel agent B2C in Indonesia. A total of 200 respondents were using probability sampling. A questionnaire was used as a research instrument to collect data from respondents. The analisis technique used is a verification technique using of SEM. The research shows that online customer review has an influence on online booking intention.
\end{abstract}

Keywords: online customer review, online booking intention.

\section{INTRODUCTION}

The penetration rate of internet users both in the world and in Indonesia continues to increase every year. Several studies suggest that the development of the internet has changed the business model in various industries, one of which is the travel industry, namely the existence of an online travel agent. In the 2019 report, We Are Social includes data related to the development of e-commerce. It is the online travel industry which has experienced growth from both globally and in Southeast Asia, which is $11 \%$ and $17 \%$ [1].

The growth of online travel has made Indonesia become a potential market for developing online travel agents. The Indonesian Travel Agent Association (Astindo) said that the majority of the conventional travel market segment was eroded by the presence of digital travel platforms or better known as online travel agents, more than half of the existing market has switched to digital [2].

Online travel agents in numbers show very rapid growth, but when compared to other industries which are part of Indonesia's internet economic resources, it gets the slowest growth. Google TEMASEK data in 2019 showed that online travel agents got $17 \%$ growth while other industries got faster growth, such as e-commerce $48 \%$, ride hailing $34 \%$ and online media $31 \%$ [3].

Based on Similarweb data for 2019 which focuses on websites with the most number of visits, the ranking of online travel agents in Indonesia mostly shows a decrease in ranking and the number of visitors who have fluctuated [4]. It means that it showed the inconsistency of the community's intention to online travel agents.

Low intention is a critical issue for companies to do business in online market [5]. Online purchase intention is one of the main inputs used by marketing managers to forecast sales and determine how the actions they take will influence consumer buying behavior [6]. A deep and correct understanding of purchase intention is important for every company to know to strengthen long-term relationships with consumers [7]. Positive online purchase intention will encourage consumers to make purchases in a sustainable manner [8]. Online purchase 
intention in the travel industry is better known as online booking intention [9]-[10].

The influence factors in online booking intention include perceived usefulness, ease of the use and attitude toward [11]. Another factor that can affect online booking intention is online customer reviews, as a means for consumers to find and obtain information that will later influence purchasing decisions [12]. The study found that online customer reviews were the most important source of information for customers to generate online booking intention [13].

Based on the background of the research, the problem of this research is identified into the following central themes:

The current development of the internet has caused many businesses to switch to online businesses, one of which is travel with the birth of online travel agents which are growing every year, causing competition. Online booking intention which is owned by online travel agents in Indonesia is still low and the competition is quite high. Online customer reviews are expected to be a solution to the problem of increasing online booking intention.

Based on the explanation, the study was conducted by entitled "The Influence of Online Customer Reviews on Online Booking Intention in the Online B2C Travel Agent Industry in Indonesia" (Survey of Millennials Joined in Instagram Followers Traveloka, Tiket.com, Pegipegi, Nusatrip and Mister Aladin).

\subsection{The Problem of the Research}

1. How does the level of online booking intention describe for the millennial generation who are members of the official Instagram followers of the B2C Indonesia online travel agent?

2. How does the online customer review level describe the millennial generation who are members of the official Instagram followers of the B2C Indonesia online travel agent?

3. The magnitude of the influence of online customer reviews on online booking intention on the millennial generation who are members of the official Instagram followers of the B2C Indonesia online travel agent.

\subsection{The Purpose of The Research}

Generally, the purpose of this research is to describe online customer reviews and online booking intentions for the millennial generation who are members of the official Instagram followers of the B2C Indonesia online travel agent. In addition, this research was also conducted to empirically prove the influence of online customer reviews on online booking intention for the millennial generation who are members of the official Instagram followers of the B2C Indonesia online travel agent.
Online purchase intention is a combination of consumer concentration in buying a product and the possibility of buying [14]. Recognizing online purchase intention is very important because customers can usually be predicted by their intentions [15]. Intention is related to actual behavior and this association has been confirmed in several studies [16].

Online purchase intention can be defined das the threshold where consumers tend to buy products or services from certain websites [17]. Another opinion defines online purchase intention as a factor that predicts consumer behavior towards action to complete negotiations using the Internet [18].

Based on several definitions, the researcher concludes that online purchase intention is a consumer's desire to buy a product via the internet. Online purchase Intention arises when consumers are influenced by information about a product either in the form of quality or quality. The dimensions of online purchase intention are based on the opinion of Ferdinand (2006) in [19], including:

1. Explorative Interest

2. Preferential Interests

3. Transactional Interests

4. Relative Interests

Online customer reviews are defined as positive or negative comments about products, brands, services offered by an organization / company made by consumers in an online environment [20]. Another opinion defines online customer reviews as voluntary feedback from consumers about the purchase experience and has very potential information value for both consumers and companies [21].

Online customer reviews are important for consumers in making online purchases, when consumers cannot personally rate a product, they often rely on online customer reviews [22].

It is supported by the results of research conducted by [23], the results of this study revealed that online customer reviews have an influence on online booking intention, while the dimensions of online customer reviews include:

1. Usefulness of Online Reviews

2. Timeliness of Online Reviews

3. Positive Valance of Online Reviews

4. Volume of Online Reviews

\section{METHODS}

The method used in this research was a survey method with an explanatory approach. The research was conducted in the city of Bandung in December-April 2020 with the research population, namely the millennial generation who were members of the official Instagram followers of the B2C Indonesia online travel 
agent (Traveloka, Tiket.com, Pegipegi, Nusatrip, and Mister Aladin, accessed in February 2020). Based on the SEM sampling criteria, a sample of 200 people was obtained by using the technique of probability sampling. Then, the data collection method used was a questionnaire. The instrument used in this research used an assessment in the form of a Likert scale with a score range of 1-7. Processing the data collected from the questionnaire results can be grouped into three steps, namely preparation, tabulation and application of data in the research approach.

The data analysis techniques used were descriptive techniques and structural equation modeling (SEM) analysis with the help of IBM SPSS AMOS 22 for windows.

\section{RESULT AND DISCUSSION}

Based on the calculation of field data, it can be seen that the online booking intention assessment of the online travel agent B2C Indonesia by the millennial generation was categorized in strong category. It is caused that the ideal score contained in the online booking intention variable was 12,895 for 11 statements, while for the total score of 15,400 with a total percentage of $83.73 \%$, explorative interest, got the highest score. It was followed by preferential interest, transactional interest and referential interest.

The results show that online travel agent companies in Indonesia have succeeded in gaining high interest in online bookings from their customers. In addition, the millennial generation in Indonesia has shown a high interest in booking online through online travel agents compared to conventional travel.

The assessment of online customer reviews on the online travel agent B2C Indonesia by the millennial generation based on the calculation of field data was categorized in strong category. It can be known that the ideal score was found in the online customer review variable 13,130 for 11 statements, while for the total score of 15,400 with a total percentage of $85.26 \%$, the usefulness of online reviews got the highest score. Furthermore, It was followed by timeliness of online reviews, positive valance of online reviews and volume of online reviews.

The results showed that online travel agent companies in Indonesia have succeeded in building online customer reviews using certain strategies well, and the millennial generation in Indonesia assesses that the implementation of online customer reviews of online travel agent companies was good enough in facilitating customers to interact, discuss, provide criticism / suggestions, and primarily to obtain information relating to services or products.

\subsection{Analysis of Structural Equation Modeling (SEM)}

\subsubsection{SEM Assumption Test}

There were basic assumptions that must be fulfilled in SEM testing which consisted of sample size, data normality, data outliers, and multicollinearity. The sample size provided the basis estimating of sampling error. The samples of the research were 200 respondents. The results of data processing showed that the critical ratio skewness value was normally distributed because each variable's critical ratio value was between -2.58 to 2.58 , while the multivariate critical ratio value was -808 . The outliers data can be seen on the value of the Mahalanobis distance which had a value of $\rho 1$ and $\rho 2$. The data showed that the farthest distance from the mahalanobis d-square value was 15.483 and the closest distance was 7.898. Meanwhile, the values of $\rho 1$ and $\rho 2$ from the mahalanobis $d$-square value were obtained 0.050 and 1,000 , respectively, where one of the values of $\rho 1$ and $\rho 2$ had a value of $>0.05$. If the value of $\rho 2$ was $>0.05$ then there was no data that was considered an outlier (Santoso, 2011). Therefore, it can be said that in this research there was no data that was outliers. The output results gave a determinant value of sample covariance matrix $=77.098$. This value was far from zero. Then, it can be concluded that there was no multicollinearity or singularity in the analyzed data, so the data in this research were feasible and can be used in research.

\subsubsection{Testing of Structural Equation Model (SEM)}

The first stage was the specification of the model. It was related to the formation of the initial model of structural equations before the estimation was carried out. This initial model was formulated based on previous theory or research. Fig. 1. specifications of the initial model in this research were shown as following.

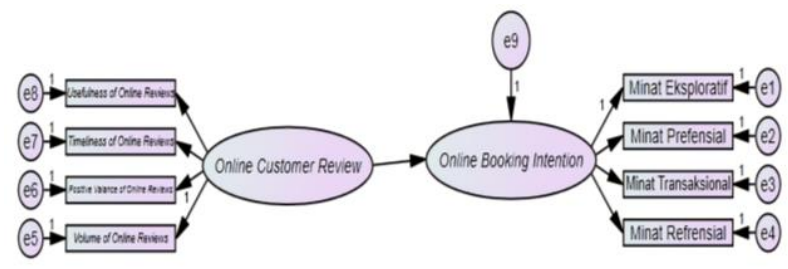

Figure 1. Model research

After the model was made, the data obtained through the testing phase of basic assumptions can be enhanced to the research model to carry out the next SEM testing phase. The data obtained consisted of 200 samples with 22 statement items including 11 items of online customer review variable statements and 11 statement items for online booking intention variables. 
Based on the results of the Measurement Model Estimation Test, it showed that all of model was appropriate and can be carried out structural testing. All indicators and construction can be said to be valid because they showed the results of the loading factor with a value of $>0.5$. The loading factor with the highest results was the usefulness of online customer reviews which formed online customer reviews with a value of 0.896, while the lowest results were shown by a reference interest in forming online booking intention with a value of 0.768 . Then, testing can be carried out to the next stage, namely testing fit based on table 1 .

Table 1. Estimate Measurement Model

\begin{tabular}{|ll|l|}
\hline \multicolumn{2}{|l|}{ Estimate } \\
\hline OBI <--- OCR & .825 \\
\hline ME <--- OBI & .791 \\
\hline MP <-- OBI & .797 \\
\hline MT <-- OBI & .894 \\
\hline MR <-- OBI & .768 \\
\hline VOR <-- OCR & .856 \\
\hline PVOR <--- OCR & .848 \\
\hline TOR <--- OCR & .881 \\
\hline UOR <--- OCR & .896 \\
\hline
\end{tabular}

The overall model fit test was carried out to evaluate generally the level of fit or Goodness of Fit (GOF) between the data and the model, validity and reliability, the measurement model, and the significance of the coefficient of the structural model. The fit test was carried out in several stages, such as the fit of the measurement model, the fit of the structural model, and the suitability of the whole model.

Exogenous Construct Measurement Model online customer review provides information about the form of the exogenous model and standardize loading factor of each manifest variable as follows fig. 2 .

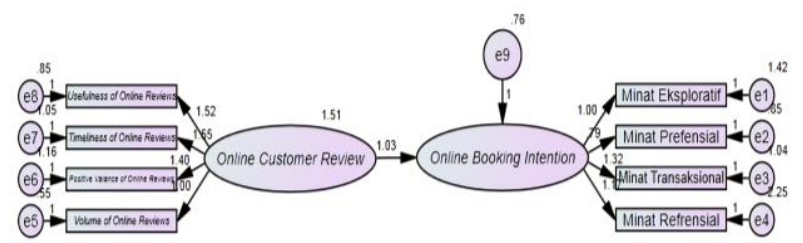

Figure 2. Online customer review exogenous construct measurement model

The results showed that all the standardized loading factor (SRW) values for each of these indicators were $\geq$ 0.5 Therefore, it can be said that the indicators of the usefulness of online reviews, timeliness of online reviews, positive valance of online reviews and volume of online reviews have good validity at measuring online customer reviews.

Based on the results of processing the value of construct reliability $(\mathrm{CR})=0.926 \geq 0.70$ and the value of Varience Extracted (VE) $=0.758 \geq 0.50$ Online customer review so it can be said that the construction had good reliability.
The Online Booking Intention Endogenous Construct Measurement Model provides information about the form of the endogenous model and the standardize loading factor of each manifest variable as follows fig. 3 .

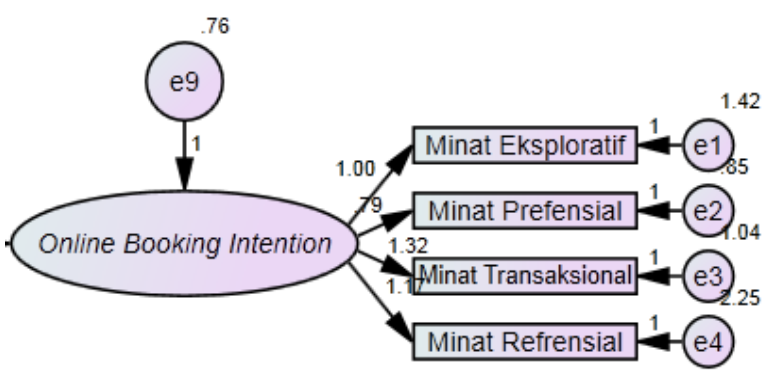

Figure 3. Online booking intention endogenous construct measurement model

The results showed that all standardized loading factor values (SRW) for each indicator was $\geqslant 0.5$. Then, it can be said that the indicators of exploratory interest, preferential interest, transactional interest and reference interest had good validity in measuring online booking intention. Based on table 5 it can also be seen that the value of construct reliability $(\mathrm{CR})$ was $=0.887$ $\geqslant 0.70$ and the value of variance extract (VE) was = $0.692 \geqslant 0.50$. Therefore, it means that the construct had good reliability, where the indicators represented the online variables well in booking intention.

Structural model analysis dealt with the evaluation of parameters that showed a causal relationship or the effect of one latent variable on other latent variables. After the goodness of fit test was carried out, the online customer review structural model of online booking intention can be said to be fit. The picture of the standardized loading factor estimation structural model was presented as the following fig. 4 .

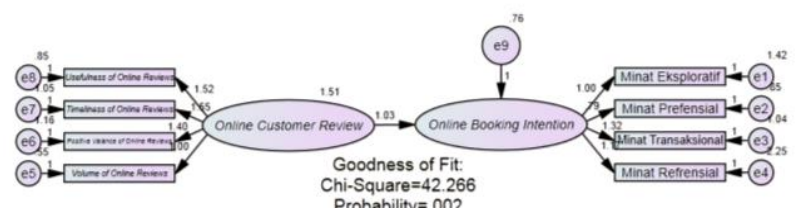

Figure 4. Structural model of the influence of online customer reviews on online booking intention

The test results for the significance of the path coefficient estimating in the model after trimming were all significant at an error rate of $5 \%$ or the P-value had a value of $\leqslant 0.05$. The $\mathrm{R}$-square online booking intention of $0.680(68 \%)$ meant that the online booking intention variable explained by the online customer reviews variable was $0.680(68 \%)$ while the remaining $32 \%$ was influenced or explained by other variables that was not examined in this research. The fit test of the whole model was carried out to generally evaluate the degree of fit or goodness of fit. In this research, there were 
criteria values that had met the requirements by having a good fit value. Then, it can be said that this model was declared marginally feasible to be used as a tool in confirming the theory that had been built based on existing observational data. As the result, it can be stated that this model was fit or acceptable.

Hypothesis testing was done by using a t-value with a significance level of 0.05 and degrees of freedom of $n$ (sample). The t-value in the IBM SPSS AMOS 22 program was the Critical Ratio (C.R) value. If the value of $C . R \geqslant$ t-table (1.96) or the probability value of $\mathrm{P} \leqslant$ 0.05 then $\mathrm{H} 0$ was rejected (the research hypothesis was accepted). The criteria for acceptance or rejection of the hypothesis in this research can be written as follows table 2 .

H0 c.r $\leqslant 1,967$ means that online customer review has no effect on online booking intention.

H1 c.r $\geqslant 1,967$ means that online customer review has an effect on online booking intention.

Table 2. Hypothesis Test Analysis

\begin{tabular}{|l|l|l|l|l|l|l|}
\hline \multirow{2}{*}{ Hyohothesis } & \multicolumn{2}{|c|}{ Estimate } & \multirow{2}{*}{ S.E } & C.R. & P & R2 \\
\cline { 2 - 7 } & $\boldsymbol{R} \boldsymbol{W}$ & \multicolumn{1}{|c}{$\boldsymbol{W}$} & & & & \\
\hline $\begin{array}{l}\text { Online Booking } \\
\text { Intention <-- }\end{array}$ & 1.032 & 0.825 & 0.95 & 10.838 & $* * *$ & 0.680 \\
$\begin{array}{l}\text { Online Customer } \\
\text { Review }\end{array}$ & & & & & & \\
\hline
\end{tabular}

The results of the data processing that had been done showed that the C.R value was 10.838 . It was $\geq \mathrm{t}$-table (1.96), which means that the relationship between online customer review and online booking intention was assumed to be correct. While the probability value was***, meaning that the $\mathrm{P}$ value was $\leq 0.05$. Moreover, the online customer review variable had a very significant effect on online booking intention. Based on the results of research and discussion, it can be said that the effect of online customer review on online booking intention had a C.R value of 10.838 with a probability of $* * *$ so that $\mathrm{H} 0$ was rejected. Then, it means that there was an influence between the online customer review variable on online booking intention.

\section{CONCLUSION}

Based on the result above it can be concluded that the description of the performance of online booking intention can be seen from its dimensions which consist of exploratory interest, preferential interest, transactional interest and referential interest which are in the high category. It means that companies in the online travel agent industry in Indonesia have obtained a fairly good level of booking intention as a whole from their customers. The dimension that received the highest response was the dimension of explorative interest, while the dimension that received the lowest response was the refractive dimension.
An overview of the online performance of customer reviews can be seen from its dimensions consisting of the usefulness of online reviews, timeliness of online reviews, positive valance of online reviews and volume of online reviews which are in the high category. Then, it can be concluded that companies in the online travel agent industry in Indonesia have shown a fairly good performance as a whole in managing online customer reviews both on social media and on their applications / websites. The dimension that received the highest response was the dimension of usefulness of online reviews, while the dimension that received the lowest response was the dimension of volume of online reviews.

Furthermore, online customer reviews have a positive and significant impact on online booking intention on the millennial generation who are members of the official Instagram followers of the B2C Indonesia Online Travel Agent

\section{REFERENCES}

[1] we are Social, "Digital 2019 spotlight ecommerce in southeast," 2019. https://wearesocial.com/.

[2] A. Dwijayanto, "Astindo: platform online keruk $60 \%$ pangsa pasar agent travel. Retrieved Februari 3, 2020, from industri.," industri.kontan.co.id. .

[3] G. TEMASEK, "E-conomy sea 2019: southeast asia's \$100 billion internet economy," 2019. Google TEMASEK.

[4] Similarweb, "Top site ranking for travel and tourism in indonesia," Similarweb.com, 2020. https://www.similarweb.com/topwebsites/indonesia/category/travel-and-tourism.

[5] H. Hsin Chang and S. Wen Chen, "The impact of online store environment cues on purchase intention," Online Inf. Rev., vol. 32, no. 6, 2008, doi: 10.1108/14684520810923953.

[6] M. Vadiveloo, V. Morwitz, and P. Chandon, "Mere belief effects: the effect of health labels on food consumption and self-reported satiety," $J$. Acad. Nutr. Diet., vol. 112, no. 9, 2012, doi: 10.1016/j.jand.2012.06.310.

[7] A. Thapa, "Consumer switching behaviour: a study of shampoo brands," Abhinav, vol. 1, no. 9, 2012.

[8] Y. W. Kristyatmoko, "Pengaruh persepsi kualitas tarhadap niat beli tablet samsung galaxy tab," $J$. Ilmu Manaj., vol. 1, 2013.

[9] L. Wang, R. Law, B. D. Guillet, K. Hung, and D. K. C. Fong, "Impact of hotel website quality on online booking intentions: etrust as a mediator," Int. J. Hosp. Manag., vol. 47, 2015, doi: 10.1016/j.ijhm.2015.03.012.

[10] O. A. El-Said, "Impact of online reviews on hotel booking intention: The moderating role of brand image, star category, and price," Tour. Manag. 
Perspect., vol. 33, 2020, doi: 10.1016/j.tmp.2019.100604.

[11] V. Venkatesh, M. Morris, G. Davis, and F. Davis, "Technology acceptance model - Research," MIS Q., 2003.

[12] A. M.AlMana and A. A. Mirza, "The impact of electronic word of mouth on consumers\&apos; purchasing decisions," Int. J. Comput. Appl., vol. 82, no. 9, 2013, doi: 10.5120/14145-2286.

[13] U. Gretzel and K. H. Yoo, "Use and impact of online travel reviews," in Information and Communication Technologies in Tourism 2008, 2008.

[14] J. W. Wu, "Green purchase intentions: anexploratory study of the taiwanese electric motorcycle market," J. Bus. Res., vol. 68, no. 4, pp. 829-833, 2015.

[15] J. H. Park and M. K. Kim, "Factors influencing the low usage of smart tv services by the terminal buyers in korea," Telemat. Informatics, vol. 33, no. 4, 2016, doi: 10.1016/j.tele.2016.01.001.

[16] C. L. Hsu, M. C. Chen, K. Kikuchi, and I. Machida, "Elucidating the determinants of purchase intention toward social shopping sites: a comparative study of taiwan and japan," Telemat. Informatics, vol. 34, no. 4, 2017, doi: 10.1016/j.tele.2016.04.016.

[17]H. E. B. Sakalli, "Online purchase intention: purchase orientations and expected benefits," Int. J. Sci. Res. Publ., vol. 8, no. 5, 2018, doi: 10.29322/ijsrp.8.5.2018.p7714.

[18] I. Ventre and D. Kolbe, "The impact of perceived usefulness of online reviews, trust and perceived risk on online purchase intention in emerging markets: a mexican perspective," J. Int. Consum. Mark., vol. 32, no. 4, 2020, doi: 10.1080/08961530.2020.1712293.

[19]R. E. Marie, "Pengaruh online reviews terhadap online hotel booking intentions," Study Kasus pada Travel. J. Ilm. Pariwisata, vol. 24, no. 3, pp. 194-207, 2019.

[20] O. Zablocki, L. J. van Zyl, B. Kirby, and M. Trindade, "Erratum: correction: zablocki, o.; et al. diversity of dsdna viruses in a south african hot spring assessed by metagenomics and microscopy. Viruses 2017, 9, 348 (Viruses (2017) 911 PII: E17)," Viruses, vol. 10, no. 1. 2018, doi 10.3390/v10010017.

[21]Z. Liu, C. Zhang, Y. Guo, M. Osmani, and P. Demian, "A building information modelling (bim) basedwater efficiency (bwe) framework for sustainable building design and construction management," Electron., vol. 8, no. 6, 2019, doi 10.3390/electronics8060599.

[22] A. Yaylí and M. Bayram, "E-wom: the effects of online consumer reviews on purchasing decisions," International Journal of Internet Marketing and Advertising, vol. 7, no. 1. 2012, doi: 10.1504/IJIMA.2012.044958.

[23] S. W. L. Fong, T. P. Kian, Y. S. Fern, and S. L. Quan, "The impact of online consumer review to online hotel booking intention in malaysia," Int. J. Supply Chain Manag., vol. 7, no. 2, 2018. 